\title{
Halal Products: Not Restricted to Food and its Marketing Opportunity in the Muslim
}

\author{
World \\ * Dr. Muhammad Tariq Khan, Associate Professor \\ ** Dr. Tariq Iqbal Khan, Assistant Professor (Corresponding Author) \\ ** Mr. Sheraz Ahmed, Assistant Professor
}

\begin{abstract}
Halal refers to methods of producing goods \& services in the manner allowed by Shariah or Islamic law, which invest besides food preparation and food products but also encompasses the production of pharmaceutical, Cosmetics, Garments \& fashion, Tourism Practices and also services like tourism, finance \& banking and many more. Halal not only a religious observance and obligation for Muslims but also has emerged as a powerful market force alike both for Muslims and non-Muslims, so gained an increasing acceptance among Muslims along with non-Muslim consumers. Halal is becoming a global symbol of a lifestyle choice and quality assurance choice has promoted values as economic and social justice, earth stewardship, social responsibility, and animal welfare have gained interest which is beyond religious compliance. The global halal market is 1.7 billion consumers and worth almost US\$2.3 trillion. This paper has focused on items Muslims are using other than food.

Keywords: Halal-market, Halal-Pharmaceuticals, Halal-Cosmetics, Halal-Tourism, Halal-dress

Introduction

Muslims eat permitted food and avoid what is not allowed. The halal concept refers to methods of producing goods \& services in the manners allowed by Shariah or Islamic law, which besides food preparation and food production also encompasses the production of pharmaceutical, practices of finance (Bohari, et al., n.d; Balan et al., 2020). Halal is not only a religious observance \& obligation for Muslims but also has emerged as a powerful market force alike both for Muslims \& non-Muslims and gained an increasing acceptance among Muslims along with non-Muslim consumers. Halal becoming a global symbol of lifestyle choice \& quality assurance choice has promoted values as economic \& social justice, earth stewardship, social responsibility, \& animal welfare has gained interest which is beyond religious compliance (Elasrag, 2016; Pawestri, 2019). Halal business is profitable in both Muslim countries as well as non-Muslim countries where demand for halal products is significantly growing e.g. Russia, Thailand, Japan, South Korea, Spain, \& Mexico have already established halal industrial activities. The halal business has promising opportunities and Malaysia stands first in halal industry market size and Indonesia stands tenth. Other Muslim countries are ranked in order as UAE, Bahrain, Saudi Arabia, Pakistan, Oman, Kuwait, Qatar, and Jordan (Rachman \& Syamsuddin 2019; Siregar, 2018). Once halal is taken as a choice of lifestyle then for halal the range of options increases exponentially (Razak et al., 2015). Religious compulsion on Muslims to consume halal drink, food, \& medicine created the halal product market by stimulating halal product demand. Halal products globally have 2 billion consumers that are yearly growing at the rate of 20 percent, so the halal market in the world spans from food to tourism \& finance is worth US\$ 3 trillion (Memon, 2015). Haram \& Halal is not only restricted or limited or concerning about food, drinks $\&$ services products but encompass all the things or matters of daily life that come in contact in daily life especially used by Muslims, such as food $\&$ beverages, cosmetics $\&$ pharmaceuticals, media \& communications, services like finance \& banking, tourism \& travel, garments \& fashion, and recreation, (Wahab, 2004; Murti, n.d.; Ab-Talib \& Johan, 2012; Razak et al., 2015 \& Krishnan et al., 2017). Thomas Router forecasted that the global Muslim food market will be worth US \$: 1626 billion, pharmaceuticals 97 billion, cosmetics 39 billion
\end{abstract}

\footnotetext{
* Department of Management Sciences, The University of Haripur Email: tariq_phd@ yahoo.com

** Department of Management Sciences, The University of Haripur Email: tariqfirst@gmail.com

*** Department of Management Sciences, The University of Haripur Email: sherazahmed@uoh.edu.pk
} 
Susilowati et al. (2018) narrated that now halal has become a global concept and stands for fair business as well as for social justice, sustainable environment, and animal welfare. Besides covering animal slaughtering for Muslims' eating according to Shariah it also encompasses products $\&$ services of the highest quality meeting the ever-increasing needs \& awareness of Non-Muslim consumers.

The data of halal oral used (food etc.) \& other products are given in the following diagram: T The data of halal oral used (food etc.) \& other products are given in the following diagram:

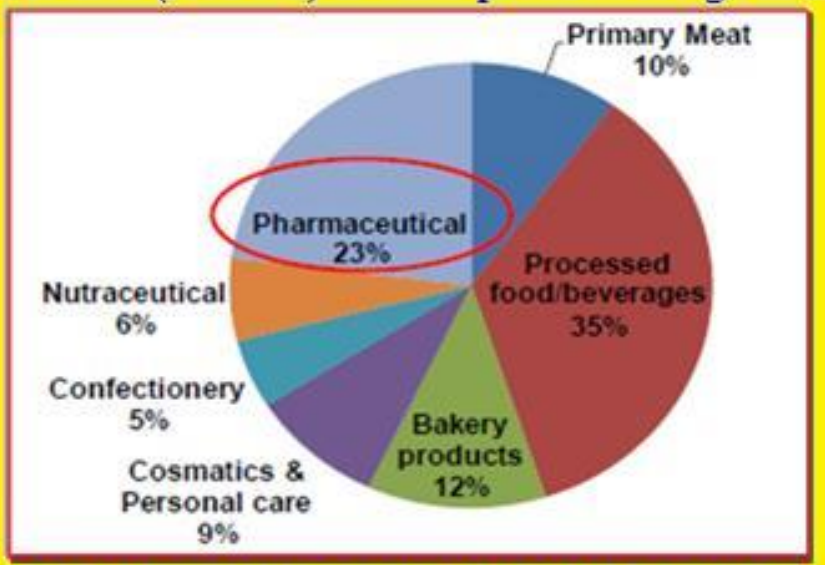

Source: https://azkahalal.files.wordpress.com/2014/05/t-15-mian-riaz.pdf

What is Halal?

Source: https://azkahalal.files.wordpress.com/2014/05/t-15-mian-riaz.pdf

(2010); Samori et al. (2014); Rahim, Zainuddin, and Sariwati (2016), and Elasrag (2016) revealed that the Halal term derived from the Holy Quran which describes objects and actions. Yasid, Farhan, and Andriansyah (2016) also expressed that the halal word is absorbed from the Arabic language word alhalal giving the meaning of permissible. Yasid et al. (2016), Golnaz, Zainalabidin, and Mad Nasir (2010); Ab-Talib \& Johan (2012); Rahim et al. (2016) and Elasrag (2016) expressed that halal is a way of life which is not restricted to types of food consumed by Muslims who are more knowledgeable \& aware about their food for leading a meaningful life. Islam being a natural way of life encompasses an economic system that is based on human brotherhood, cooperation, consultation \& dietary laws. Annabi, \& Olajumoke (2017) mentioned that because of increasing market internalization many choices of market products consisting of new ingredients formulation are available. Based on Shariah some ingredients are not suitable for Muslim consumers because of their processing methods or sources. Qureshi et al. (2012); Hussain et al. (2014) and Krishnan et al. (2017) quoting various studies stated that the term "Halal" is designated for anything, entity, object, or action which according to Quran \& Sunnah is permissible to engage in the purchase, implied to the body, or use. Islam \& Chandrasekaran (2013) narrated that the 'Noor index' measures consumer perceived Halalness of brands. Many multinational companies scored very well on Noor Index. There is a considerable overlapping between Vegetarian, Islamic \& Green marketing leading to speculation that there is room to expand market potential \& shape marketing strategy with halal certification.

\section{Diagram Comparing Total Consumption (red color) and Halal Consumption (blue color)}

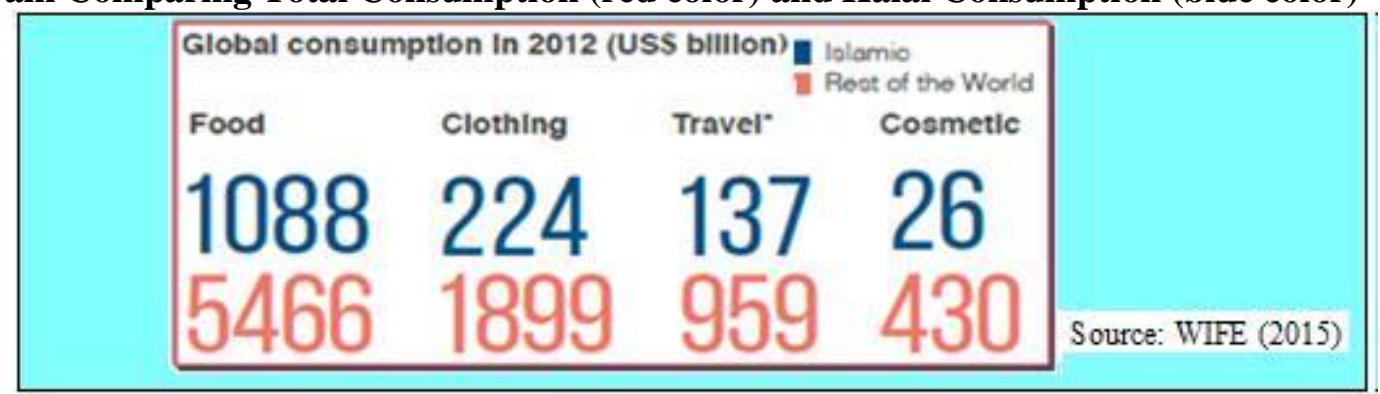

Source: WIFE (2015)

\section{Halal Market Extent}

Wilkins et al. (2019) expressing the extent of the halal products market revealed that in the world Muslims' population is 1.6 billion representing 23 percent of the global population and faithful 
Muslims consume halal products permissible under Islamic law. The market of halal products is estimated to exceed the US $\$ 2.1$ trillion in value whereas the annual market for only halal food is the US \$ 632 billion representing 16 percent of global food consumption. Besides this Wilkins et al. (2019) further narrated that based in non-Muslim countries manufacturers \& retailers of food such as some non-Muslim countries fast-food chains \& International restaurants like McDonald's, KFC, Subway, Pizza Express, \& Nando's now provide halal food.

Abuznaid (2012) revealed that it is estimated in the world halal market is the fastest growing market at an annual rate of $15 \%$. Abuznaid (2012) and Elasrag (2016) quoting several studies revealed that it is estimated that the halal industry with an annual growth rate of 15 to 20 percent is one of the fastest-growing consumer's segments with a yearly value of US\$ 560 billion \& total worth of US \$ 2.3 trillion with 1.8 billion consumers. Ab-Talib \& Johan (2012) revealed quoting some studies that 70 percent of Muslim consumers follow halal standards so the halal food market comprises a population of 1.5 billion people giving a market worth more than US\$ 600 billion. Sugita (2017) stated that the Halal industry including the food sector in recent years has significantly grown and gained much importance and the halal food sector by 2019 will grow in sales US\$ 2.5 trillion becoming 21.2 percent of global food expenditure. Razak et al. (2015) expressed that for halal products consumer base in the global market is 1.7 billion consumers and worth almost US\$2.3 trillion, making the halal market an important segment of the global market. The traditional markets lying in Asia and the Middle East but due to globalization effects, there is a significant development of halal market size in the USA \& Europe. Yasid et al. (2016) expressed that the Muslim market reached the US \$ 2001 billion, in 2013, or 12 percent of the global market. In 2013 for hall food Muslim Market increased to the US \$ 1292 billion or 17.7 percent, of the total world food market. Bohari et al. (n.d) asserted that MIDA (Malaysian Investment Development Authority) in 2013 valued the global halal food industry between US\$ 600 billion \& US\$ 2.3 trillion but it is not to focus only the halal food consumption but must also be concerned about all the supply chain process, $\&$ standard of food according to Shariah. Halal supply chain encompasses managing process of halal food products of different suppliers' points to different buyers' points located at various places especially who are simultaneously engaged in managing non-halal food items to satisfy their all types of customers. Especially in the situation when Muslim food consumers became more aware and not only concerned with the ingredients of the food for halal or non-halal aspects but also concern about entire activities in the supply chain to ensure that their consumable product is truly halal.

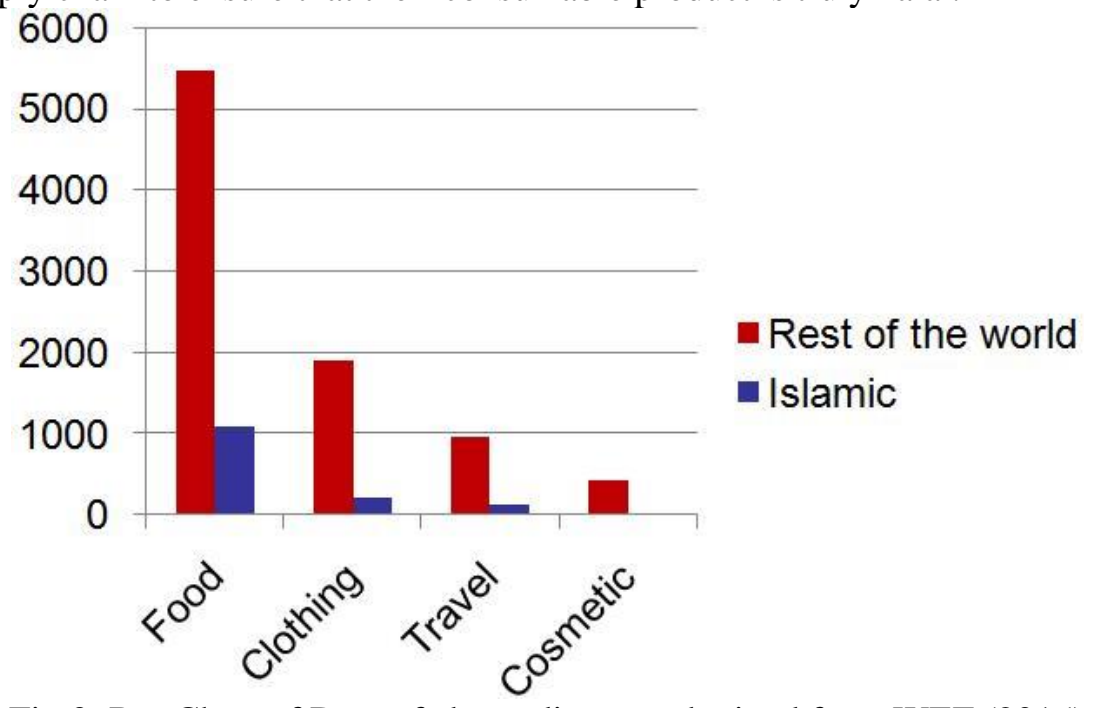

Halal Market Dimensions

Fig 3: Bar Chart of Data of above diagram obtained from WEF (2015)

Wahab (2004) stated that halal products are not only limited to food but encompass all the things that come in contact in daily life especially used by Muslims. Islam and Chandrasekaran (2013) and Aisyah (2017) are of the view that traditionally Islamic marketing or Halal concept was understood to apply to food items, and financial \& banking services only but now its consciousness is increasing and extended for all other consumable products like cosmetics \& personal care products, pharmaceuticals, entertainment \& leisure, education, fashion $\&$ toiletries, and tourism \& hospitality services. 
Wilkins et al. (2019) asserted that the halal concept applies to all products including food, pharmaceuticals, fashion, banking, insurance, entertainment, and tourism. For most Muslims halal protocol for food is most important as compared to non-food products.

According to Razak et al. (2015) and Krishnan et al. (2017), Halal \& Haram branding though for some products being in early stages is not a new concept and is not restricted to products comprising food, drinks \& services only but encompasses all the matters of daily life \& usage. The concept and usage of Halal make Muslims different from other religions. Hence while using pharmaceutical, cosmetics clothes it is to be ensured that their ingredients are halal, even care is to be taken for environment \& jobs, etc. Therefore Elasrag (2016) asserted that Muslims must ensure that the source of the food they consume is halal. It means that not the ingredients themselves but the process as a whole is according to Islamic laws. Samori et al. (2014) in a study about Malaysia narrated that as a halal hub establishment is a worldwide collective effort of many industrialists in food, cosmetics, pharmaceuticals, packaging \& logistics along with services.

Murti (n.d.) revealed that 'Halal lifestyle' is seen as a new life pattern \& the global market needs to respond to the preferences, distinctive needs, $\&$ market orientation as well as its trade $\&$ economic values. Halal market development which is food \& beverages, cosmetics \& pharmaceuticals, media \& communications, finance, tourism \& travel, garments \& fashion, \& recreation, offers a real opportunity in the region to support growth.

Ab-Talib and Johan (2012) narrated that halal is more than concerning about food. Halal besides food products encompasses products like pharmaceuticals, cosmetics \& also services like tourism, finance \& banking. Elasrag (2016) quoting several studies revealed that in recent years global halal industry is not restricted to items related to food only but has also encompassed many other items such as health products, pharmaceuticals, medical devices, toiletries, \& cosmetics and service sector items electronic \& print media, logistics, packaging, financing \& branding, and as now affluent Muslims number has increased the halal industry further widened to lifestyle offering which also includes, fashion as well as hospitality services \& travel.

Ali et al. (2019) also expressed that Qur'an \& Sunnah explain clearly haram \& halal ingredients, in food, cosmetics, toiletries, pharmaceuticals, investment, finance, \& services like the supply chain \& tourism industry. Items expected to be avoided are, food, products \& services containing haram elements of alcohol, animal remains particularly in cosmetics, \& riba.

Demirel \& Yasarsoy (n.d.) narrated that using food \& drink, products of personal care, dressing equipment, cleaning, staying in accommodation establishments, having trips are the main \& common, products $\&$ services. Many people exert efforts to consume healthy products $\&$ services.

Nain et al. (2013) revealed that the pharmaceutical market per year is estimated to be worth 800 billion US Dollars globally and this market share of Muslims is estimated to be in hundreds of billion dollars.

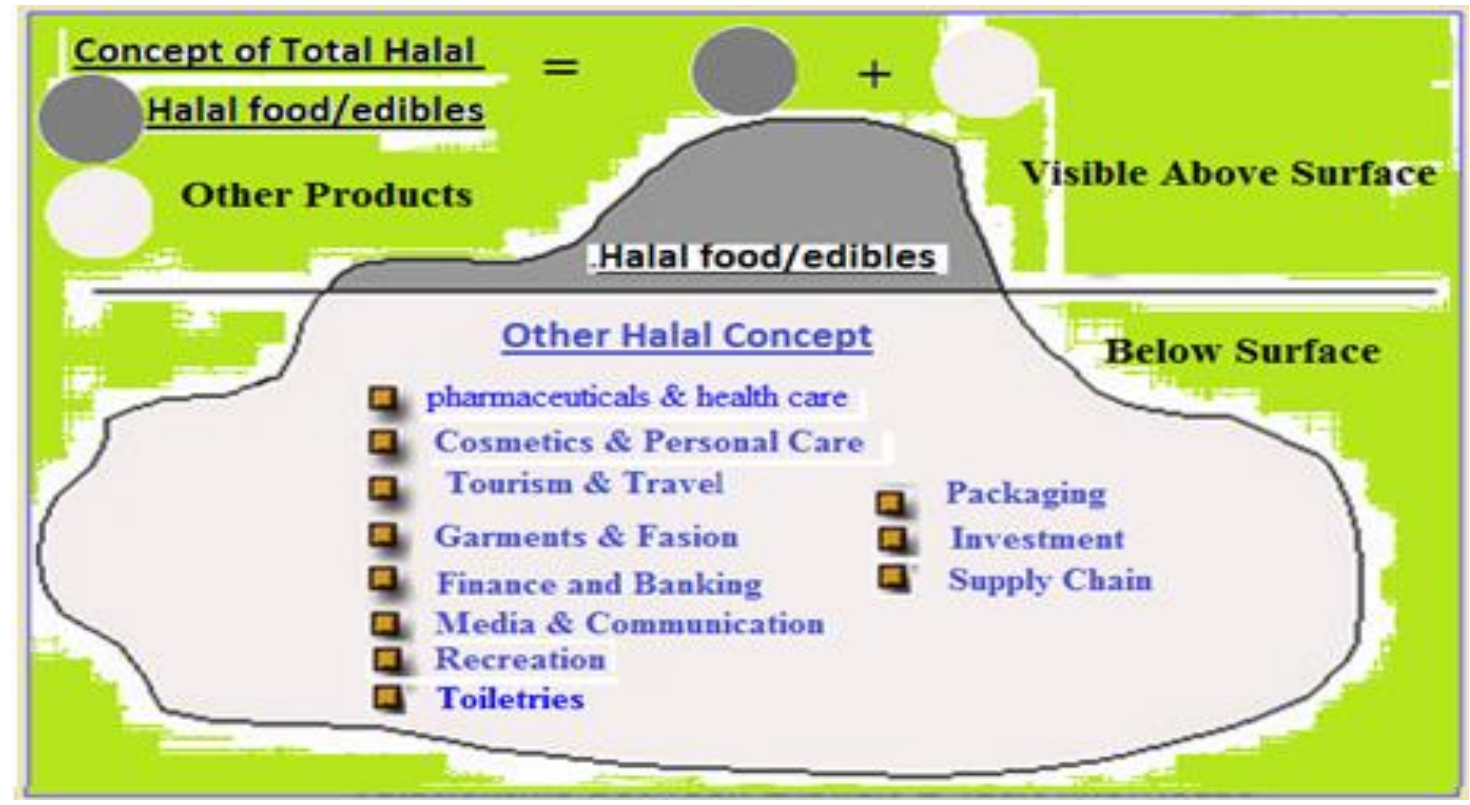

Fig 4: Iceberg diagram showing hidden segment of the halal market beyond the concept of food 
Source - Self-developed by author from data of quoted literature

\section{Pharmaceutical \& Healthcare Products}

Nain et al. (2013) revealed that the pharmaceutical market per year is estimated to be worth 800 billion US Dollars globally and this market share of Muslims is estimated to be in hundreds of billion dollars.

Razak et al. (2015) believe that health care \& personal hygiene products, cosmetics \& toiletries are appraising halal options. Halal is recognized once as a lifestyle choice for halal products the options' range will increase exponentially.

Elasrag (2016) stated that pharmaceutical \& health products are a vast grown area in the world halal industry. In Muslim-majority countries, the estimates of demand for generic medical, pharmaceutical, healthcare products \& wellness are about US\$ 555 billion. For pharmaceuticals, the market growth worldwide increased by 4 percent in 2009 to a value exceeding the US \$ 820 billion offer to halal pharmaceutical industry big potential opportunities to tap into. Increasing costs of healthcare providers a key differentiation factor to the halal market in generic pharmaceutical supply.

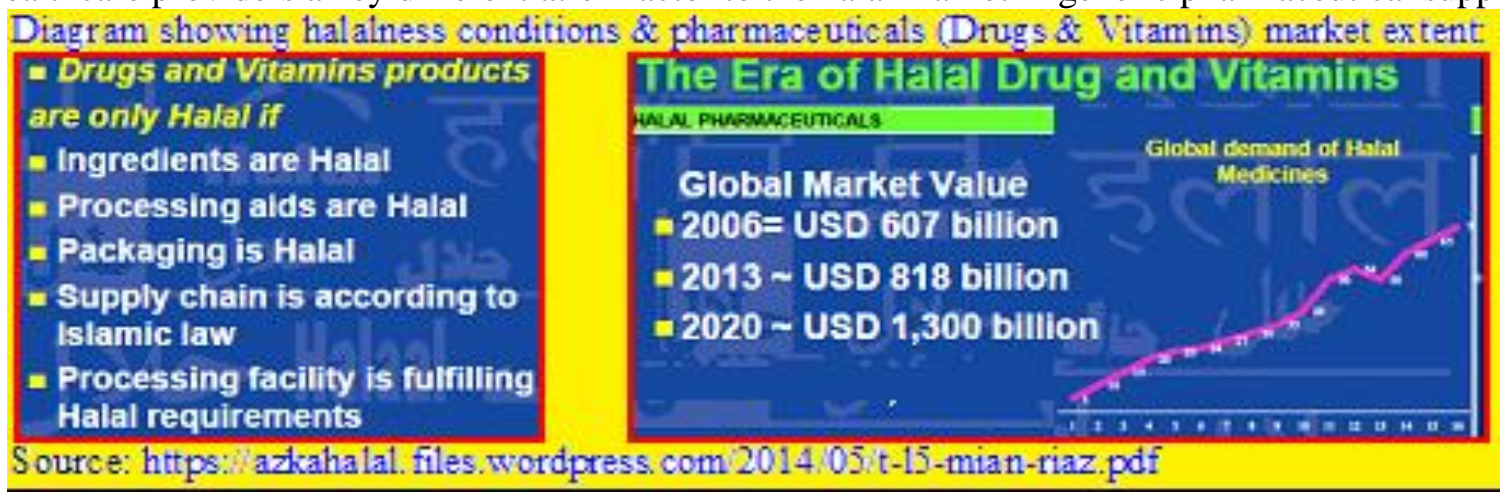

Source: https://azkahalal.files.wordpress.com/2014/05/t-15-mian-riaz.pdf

Islam \& Chandrasekaran (2013) stated that the demand for halal pharmaceuticals for Muslims is growing. The long-standing issue is of the use of gelatin, which, is protein and can be obtained normally from two sources, from cow bone $\&$ hide (bovine) a halal source, and pig (porcine) a haram source. Alcohol (ethanol) is another avoidable ingredient in halal pharmaceuticals.

Islam \& Chandrasekaran and Elasrag (2016) revealed that for halal pharmaceuticals Malaysia introduced first time a new standard in the world under the codename "MS2424:2010 (P): Halal Pharmaceuticals General Guidelines" pharmaceutical product manufacturing \& handling ensuring permission of products under Sharia laws, strengthening the medicines \& health supplements manufacturing \& servicing. This standard addresses the supply chain of the whole pharmaceutical industry from processing to packaging, labeling, distributing, handling, storing, \& medicine $\&$ health supplement display.

Murti (n.d.) stated that Islam stresses Muslims to provide their body comfort \& health. Therefore Muslims should lead a healthy life and take their body care with nutraceuticals. It is estimated that Muslims used the US \$ 134 billion pharmaceuticals \& cosmetics in 2015 including vaccines to avoid Meningitis during the pilgrimage. France, Swiss, and Germany exported to Muslim countries pharmaceuticals of US $\$ 4.68$ billion, 4.38 billion, \& 3.99 billion respectively.

The data of Pharmaceuticals (Drugs \& Vitamins) products are given in the following diagrams:
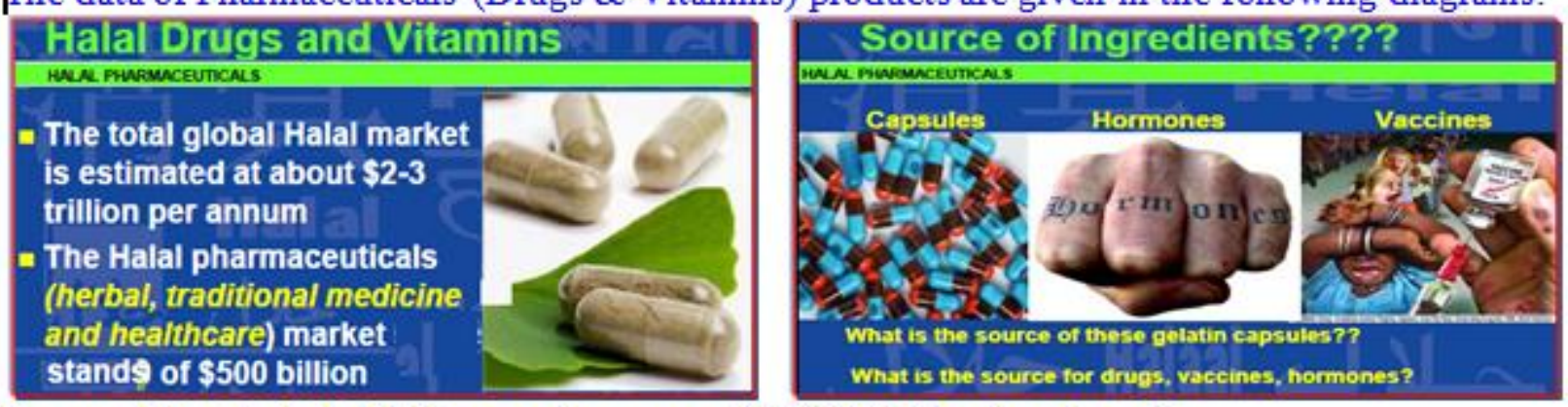

Source: https://azkahalal.files.wordpress.com/2014/05/t-15-mian-riaz.pdf

Source: https://azkahalal.files.wordpress.com/2014/05/t-15-mian-riaz.pdf 


\section{Cosmetics \& Personal Care Products}

Wahab (2004) stated that halal is not confined to food only but encompasses all the things coming in contact with daily life especially Muslims used products. Cosmetic products made from chemicals \& plants are permissible except harmful for health products being poisonous. Cosmetics made from halal animal sources not containing filth are also halal and their use is permissible. Batu \& Regenstein (2010) expressed that halal products certified responsibly are gaining acceptance as a benchmark for quality \& safety assurance.

Islam \& Chandrasekaran (2013) asserted that the halal concept also affects non-food products; particularly, products touching the body in manners other than as food, e.g. pharmaceuticals, cosmetics, products of personal care, or even clothes. In cosmetics, the trend of halal choice is catching up with Muslim consumers. Cosmetics are only considered halal when all ingredients comply with halal \& Shariah requirements and Haram ingredients such as material derived from pig, \& alcohol are not used in their preparation. Moreover, all the contents must be manufactured, packaged, and stored, and delivered according to strictly followed halal standards. Halal cosmetics market sale is estimated to range yearly from the US \$ 5 to 14 billion.

Razak et al. (2015) believe that healthcare products \& personal hygiene, cosmetics \& toiletries all are appearing in halal options.

Elasrag (2016) expressed that analysts are of the view that after the halal food industry, next in growth line is the cosmetics \& personal care industry in the global halal market because halal cosmetics products have gained momentum in eco-ethical consumers ready to pay for products of organic, earthy \& natural cosmetics matching their modern lifestyle. This is because of the high demand for halal beauty products \& cosmetics stemming from demographics of religiously conscious, young \& professionally dynamic population of Muslims. The concepts though very new in the scope of halal cosmetics spans to aspects of the production of cosmetics using halal ingredients and permissible substances required to be manufactured, packaged, stored \& distributed according to Sharia demands. There is a growing demand for halal cosmetics \& personal care products from conscientious customers becoming more selective in their choice so the Halal cosmetics market in Asia \& the Middle East is booming while halal cosmetics across the Middle East registered annual growth reaching the value of US\$ 12 billion \& in Asia especially in Indonesia \& Malaysia \& in Europe, there is a surge of interest of halal cosmetics. Halal cosmetics in Malaysia contribute 10 percent to 20 percent of the cosmetics market.

Adiba (2019) and Elasrag (2016) asserted that halal cosmetics market growth is mirrored by augmentation of customers' knowledge about the products and awareness about ingredients used in it. They also asserted that currently halal cosmetic industry all over the world is estimated at 13 billion US Dollars that accounts for 11 percent of global industry and yearly growing at the rate of 12 percent. Halal cosmetic products by consumers are considered safe, clean \& of high quality. Halal cosmetics products do not contain any ingredient derived from alcohol, pork or their derivatives so halal products are different from generally produced cosmetics.

Elasrag (2016) expressed that many products \& market of cosmetics is also plagued with the nonavailability of halal standards in the world. A collaboration of halal cosmetics products in the world market with interest groups such as ethical, organic, vegan \& environmental rights may be helpful to strengthen the value of halal cosmetics products.

Murti (n.d.) stated that Islam emphasizes its followers to see both their soul \&body because the human body has the right to comfort \& health. Therefore Muslims should lead a healthy life \& take their body care with nutraceuticals \& cosmetics and also use vaccines to prevent Meningitis while pilgrimage touring, \& perfuming. So the USA, France \& Germany respectively export to Muslim countries cosmetics of US \$ 11.05, 16.64, and 11.17, billions.

Ali et al. (2019) asserted that though halal cosmetics has a substantial share in the market because its demand has increased \& gained substantial momentum due to the need for hygienic, safe human body-friendly cosmetics but there is scarcity accessibility \& supply of these halal cosmetics \& personal care products and it is a stirring concern for halal cosmetics industry development. One cause of halal cosmetics shortage is the continuous increase in consumers' awareness and knowledge of non-halal ingredients such as lard, gelatin, swine placenta, alcohol \& collagen. Therefore because of consumers' knowledge \& awareness about the ingredients of products, cosmetic manufacturers have to produce $100 \%$ halal products. Hence Muslims have no way but to consume non-halal 
cosmetics that are manufactured by non-Muslim producers, who cannot assure 100 percent halalness of products because of lack of religious knowledge. Cosmetic items manufactured by non-Muslims contain DNA, porcine \& gelatine, lard \& pork which render the product nonhalal.

Sugibayashi, et al. (2019) mentioned that along with Muslims exhibiting high loyalty towards halal cosmetics products halal cosmetics also carry a wider demand from non-Muslim consumers, who attribute halal products and goods with better stringent standards of quality assurance \& ethical consumerism.

Suki and Suki (2018) revealed that consumers of halal cosmetics having a positive attitude towards products of cosmetics while buying look always for Halal label. They have a strong belief that the usage of halal cosmetics is important for them. Purchasers' attitude towards products of halal cosmetic is affected by some aspects such as religiosity \& knowledge. Globally market of halal cosmetics is rising, and in the Middle East sale of cosmetics \& related products is US \$ 12 billion and demand is anticipated to rise until 2024 at the annual rate of 6.8 percent. The market of cosmetics in Europe, Malaysia \& Indonesia is uprising.

Sugibayashi, et al. (2019) asserted that halal cosmetics must not contain any ingredient derived from carrion, pig, human body parts, blood predatory animals, and insects \& reptiles. Ingredients Halal cosmetics derived from halal animals must be slaughtered according to Shariah are considered halal. During manufacturing, preparation, processing, transporting, and storing of these halal products maintain pure and hygienic conditions must be ensured continuously.

Diagrams show Halalness \& Ingredients source of Cosmetics (Drugs \& Vitamins) products:
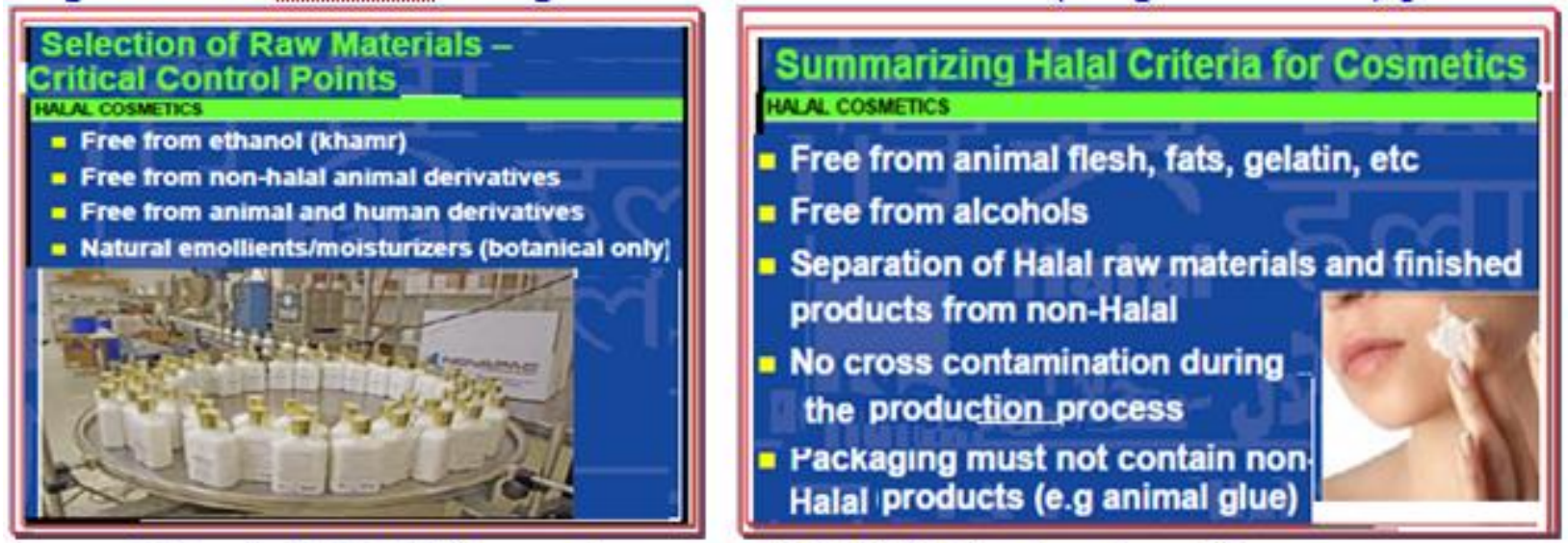

Source: https://azkahalal.files.wordpress.com/2014/05/t-15-mian-riaz.pdf

Source: https://azkahalal.files.wordpress.com/2014/05/t-15-mian-riaz.pdf

Elasrag (2016) expressed that the world cosmetics industry is dominated and to some extent monopolized by companies of non-Muslims posing a challenge to halal ingredients issue in the manufacturing of cosmetic products such as alcohol which is haram in Islam \& animal sources components such as gelatin \& collagen deemed impure.

\section{Clothing \& Equipment}

Wahab (2004) stated that equipment \& clothing made from leather, fur (except dogs \& pigs), or plants whose slaughtering, preserving \& tanning is according to Islamic principles are halal and their use is permissible.

Murti (n.d.) stated that Muslim women buy halal fashion items including garments, hijab \& its accessories, amounting to the US \$ 44 billion, in 2015. As regards halal garments the raw material for fabricating coarse or fibrous clothing the raw material used is a polyunsaturated fatty acid from the transformation of lard. Muslims during praying are required to wear good quality clothing as a thankfulness \& celebration of the blessing of God Almighty on them. However, swine hide to prepare jackets \& hair for cosmetics or swine leather for shoes is strictly forbidden.

\section{Tourism \& Travel}

Abuznaid (2012) revealed that traveling market like Indonesia, Malaysia Turkey, Saudi Arabia, \& Singapore has shown a strong interest in Muslim facilities, Products \& accommodation. The annual growth rate of Islamic hospitality markets \& hotels complying with Sharia is very fast. Islamic tourism is estimated to grow at an annual rate of 20 percent. 
Elasrag (2016) revealed that halal tourism which traditionally associated with hajj \& umrah pilgrimages. Halal tourism refers to products providing hospitality services according to laws of Shariah, Islamic beliefs \& practices i.e. providing halal food, offering prayers facilities, alcohol-free dining corners, beach area for swimming only for women with Islamic principles, arranging separate spa, swimming pools \& leisure activities for men \& women. By 2020 expenditures of Muslim tourists on tourism are estimated to rise almost 13 percent of global tourism. The halal tourism market is the US \$ 126.1 billion or 12.3 percent of global outbound tourism and is rising at a rate of 4.8 percent in comparison to the global average of 3.8 percent. By 2020 halal tourism is expected to reach the US \$ 419 billion. In recent years halal tourism has flourished to cater needs of Muslim travelers for enjoying holiday services which is also addressing their religious needs \& Islamic culture \& customs and many countries have started tourism offers of providing accommodation \& facilities under Muslims' religious beliefs, therefore Egypt, Turkey \& Malaysia, and some non-Muslim countries i.e. France, Singapore \& Australia expressing strong tendency in halal tourism also became a favorite destination of Muslim tourists.

Samori and Fadilah (2013) quoting several studies expressed that recently the new concept of tourism called halal hospitality \& tourism of Islamic tourism similar to the halal food concept has grown \& recognized by many countries. After September 11, 2001, there is a drastic drop in Muslim tourists of the Middle East to the USA, UK, and Muslim tourists shifted their destination to Muslim countries which now becoming popular tourist destinations.

Islam and Chandrasekaran (2013) revealed that "Halal Tourism" is a subclass of religious tourism and to Muslims during this tourism hotels do not offer alcohol and for men \& women have separate spa \& swimming pool facilities, \& also offer halal-certified food \& prayer rooms, and generally Muslim friendly environment. Commonly it is associated with countries of the Middle East where especially Muslims come for Hajj \& Umerah, as Muslims from all over the world come to Makkah \& Madina. Tourism is harmonious with Islam as verses from the Holy Quran to achieve physical, spiritual \& social goals endorse traveling. Thus tourism is harmonious to Islam under the obligation of religious demands regarding food, conduct, prayer, \& dress. Examples are in Dubai Al Jawara Garden Hotel whose staff is well versed with Islamic requirements of guests, the all-female staff wears hijab \& halal food is served. Similarly, New Zealand Tourism \& Christ Church Airport recently launched a new culinary guide of tourism which focuses on meeting the halal need of travelers and informing travelers about classified café \& restaurants, \& halal-certified dishes.

Murti (n.d.) expressed that halal tourism also includes Shariah-compliant hotels easily achievable by poor Muslims, attracting Muslim travelers, and which also help to the growth of the economy.

Comcem (2016) asserted that "Halal Tourism"\& "Islamic Tourism" are equated while referring to products \& services of tourism meeting the needs of Muslim travelers who do not compromise with their needs based on faith while traveling for permissible purposes. COMCEM (2016) also narrated that around the world hotel chains have started to accommodate Muslim travelers to enter into the profitable MFT market. However, in this area, there is a lack of certification \& standardization has become very clear where every hotel is following its own adopted standards. Some hotels offer only halal food while others offer besides other facilities such as prayer rooms \& gender-separated entertainment. Some hotels have obtained halal certification from certifying bodies. Many shopping, entertainment, \& cultural venues have started providing halal food and offering spaces for prayers. Some recreational facilities like spas have started to provide Muslim travelers some tailored services as gender-separated "halal" spas. The number of Halal certified restaurants is increasing in many countries offering certified halal food.

\section{Islamic (Halal) Finance}

Islam and Chandrasekaran (2013) are of the view that traditionally Islamic marketing or Halal concept was understood to apply to food items and financial and banking services only.

Ahmad (2014) believes that halal products along with Islamic banking are also considered Islamic products. Halal industry has a strong potential in international as well as in domestic markets \& almost 70 percent of Muslims are following halal food standards. In 2007 the world halal market yearly stood for US $\$ 580$ billion. Muslim population in 2014 was 1.8 billion \& the halal global market was US \$ 2.1 trillion. WEF (2015) reported that the Islamic finance industry globally was valued in 
the first half of 2014 at the US \$ 1.9 trillion approximately and estimated to exceed the US \$ 2 trillion by the end of 2014 .

Rachman and Syamsuddin (2019) asserted that the halal economy is the joint concept between the halal industry \& Islamic finance. Islamic finance refers to financial transactions \& banking transactions conducting methods according to Shariah law because both industries derive their principles \& values from the same source that is Holy Qu'ran \& Hadith. So the relationship between both is seen from the basic side of the principles of Shariah.

WEF (2015) commented that now Shariah following Islamic finance is a US \$ 2 trillion industry and in Islamic countries economic growth demand is creating the need for more bank services, creating more wealth to be protected through Islamic Insurance services or takaful and investment of funds in Sukuk called Islamic bonds \&, infrastructure \& other developments. Islamic finance is a significant beneficiary \& key driver for both speedy growth and also increased intraregional trade in South America, Africa, Asia, \& Middle East (SAME). WEF (2015) further expressed that the worldwide expansion of the Islamic economy increased by integration between global Islamic finance \& halal industry, in providing funds as well as, in delivering the end products.

Hayata et al. (2011) expressed that certification and standardization are very popular ways of reducing costs of transaction and there are economies of getting financial products certified as Islamic. Islamic law commands Muslims to invest in assets that are halal according to Islam. To identify halalness of investment in financial products a market has been created called the market for halal certification of financial products. However, it looks that the halal certification market has obtained smaller attention in analyzing economic institutions, which is not encouraging because halal certification is a fundamental feature that distinguishes \& separates conventional finance from Islamic finance. Hayata et al. (2011) further expressed that the aim should be to fulfill the gap between conventional \& Islamic finance, so firstly the market for halal certification must be described, and secondly inefficiencies in the process used for certification for transaction cost in empirical investigation \& theory must be identified.

\section{Packaging, Logistics \& Supply Chain of Halal Food}

Ab-Talib and Johan (2012) narrated that packaging of halal food products must also be focused on and be certified halal to have a wholesome halal product because the halal product does not matter only a consumption point, but must cover the whole supply chain aspect from the source of the product to final consumption. The status of halal packaging may be questionable because of packaging material sources from animals whose halal status is doubtful. It is also necessary during transportation to segregate sealed halal and non-halal products because if there is leakage such as of meat juice then segregation is a must. Some researchers are of the view that during packaging and shipping if any food is not according to Shariah law criteria it must be separated from halal food products considered being unclean. The images printed on the packaging must not violate Shariah law.

Elasrag (2016) highlighted that a decade ago halal food products were provided in corner shops \& with neighborhood butchers but now the halal market has shown a universal shift in the demand chain \& supply chain of halal food items.

Annabi, and Olajumoke (2017) asserted that because of growing market internalization, more choices of products in the market have become available consisting of new ingredients formulation. For Muslim consumers, some of these ingredients are unsuitable either because of their source or processing method which is not according to the law of Islam. So important on halal compliant products need is transparency in the supply chain of halal products. For this purpose, Halal Certifying Organizations (HCOs) have to play an important and crucial role, both as supply chain partners and as a link between halal consumers and halal product producers.

Bohari et al. (n.d) asserted that in 2013 the global halal food industry was between US\$ 600 billion to US\$ 2.3 trillion. It is not to focus only the halal food consumption but must also be concerned about all the supply chain process, \& standard of food according to Shariah. Halal supply chain encompasses managing process of halal food products of different suppliers' points to different buyers' points located at various places especially who are simultaneously engaged in managing nonhalal food items to satisfy their all types of customers. Especially in the situation when Muslim food consumers became more aware and concern about entire activities in the supply chain so ensure that their consumable product is truly halal. 


\section{Non-Muslims and Other Halal items}

Wilkins et al. (2019) revealed that based in non-Muslim countries manufacturers \& retailers of food because of international market saturation and global recession both foreign \& in-home markets recognized the potential of faith-based marketing. Wilkins et al. (2019) quoted that in the United States halal food hit the US \$ 20 billion on 7600 outlets, and in European countries such as UK, Belgium, the Netherlands, and France many fast-food chains \& restaurants provide only halal food products at all or some outlets. Annabi, and Olajumoke (2017) asserted that the halal concept besides emerging as a Muslim brand identifier is transcending beyond a religious issue stick with Muslims, to the mainstream market as a synonymous global symbol of quality. It is believed that halal produce is safer, healthier, \& tastier appealing to even Non-Muslims besides Muslims, and its demand is linked to this belief. Elasrag (2016) asserted that the cosmetic industry all over the world is dominated and to some extent monopolized by non-Muslim companies posing a serious challenge to the matter of halal ingredients in their manufactured cosmetic products. Sugibayashi, et al. (2019) mentioned that along with Muslims exhibiting high loyalty towards halal cosmetics products halal cosmetics also carry a wider demand from non-Muslim consumers, who attribute halal products and goods with better stringent standards of quality assurance \& ethical consumerism. Batu and Regenstein (2010) expressed that halal products certified responsibly are gaining acceptance as a benchmark for quality and safety assurance. Annabi, and Olajumoke (2017) asserted that the halal concept along with emerging as a Muslim brand identifier is now transcending to be a global symbol from merely a religious issue to synonymous with quality in the general market of the mainstream. Now halal product demand is related to the belief of being safer, healthier, and tastier, attracting alike to both Muslims and non-Muslim. Because of growing market internalization, more choices of products in the market have become available consisting of new ingredients formulation.

Ab-Talib and Johan (2012); Memon (2015) and Rahim et al. (2016) asserted referring to some researches that non-Muslims have also developed their likeness, tendency, and preference for Halal food products and prefer to purchase Halal food products due to their healthier, tastier, safe and clean characteristics. In the western countries, many non-Muslims also like halal food by developing their likeness for it and Golnaz et al. (2010) quoted an example of awareness of consumers and their understanding regarding the concept of halal food products in Moscow in Russia where the sale of halal stores increased from 45 million Dollars in 2004 to 70 Million Dollars in 2006. In 2008 Canadian Agri-Food Trade reported that in many non-Muslim countries there is a high demand for Halal products for both Muslim and non-Muslims consumers. Among non-Muslims buyers, the popularity of Halal food products is increasing because of Muslims' humane animal treatment, and because of their perception that halal food products are safer and healthier. Halal products undergo thorough inspection ensuring a hygienic and clean manufacturing process. To popularize Halal values among non-Muslims consumers awareness of society's concerns on issues regarding, safety, health, and animal rights, social justice, safety, welfare, and the environment be increased. Russian nonMuslims buy from stores of Muslims due to their confidence that products are safe, fresh, and free from infections and also believe that Muslims would not cheat because are following their religious belief. Non-Muslims in Philippine also tend to prefer Halal logo-stamped food products for health reasons because they have become health conscious.

\section{Conclusion}

From the study of the above literature it is concluded that halal now has become a global concept and stands for fair business as well as for social justice, sustainable environment, and animal welfare therefore halal products market globally have 2 billion consumers growing 20 percent annually but the halal concept is not limited to food only rather encompasses all the things coming in contact with daily life especially to Muslims' used products, such as pharmaceuticals \& cosmetics; media \& communications, services like finance \& banking, tourism \& travel, garments \& fashion, packaging, entertainment \& recreation, and supply chain. The business of Halal products is very profitable in both Muslim countries as well as non-Muslim countries where demand for halal products showed significant growth e.g. Russia, Thailand, Japan, South Korea, Spain, \& Mexico have already established halal industrial activities. Thomas Router forecasted that the global Muslim food market will be worth the US \$: 1626 billion, pharmaceuticals 97 billion, cosmetics 39 billion. 


\section{Recommendations}

According to Shariah halal business encompasses products \& services of the highest quality, are hygienic and healthy so also demanded by non-Muslims because these are meeting the everincreasing needs \& awareness of Non-Muslim consumers. Therefore Muslims should prefer to use halal products and also try to enter in halal business because still, a major share of the business is in the hands of non-Muslim companies and countries.

\section{References}

Ab Talib, M. S., Johan, M.., \& Remie, M. (2012). Issues in halal packaging: A conceptual paper. International Business \& Management, 5(2), 94-98.

Abuznaid, S. (2012). Islamic Marketing: Addressing the Muslim market. الإسلامي التسويق الإسلامي السوق: مخاطبة. An - Najah Univ. J. Res. (Humanities), 26(6), 1-10.

Adiba, E. M. (2019). The consumer purchasing behavior of halal cosmetics: A study on generations X \& Y. Journal of Islamic Monetary Economics \& Finance, 5(1), 169-192.

Ahmad, J. (2014). The role of public relations in promoting Islamic products globally: The Malaysian experience. Journal of Islamic Studies \& Culture, 2(3), 63-81.

Aisyah, M. (2017). Consumers demand halal cosmetics \& personal care products in Indonesia. Journal of Islamic Economics, 9(1), 125 - 142.

Ali, Q., Salman, A., Yaacob, H., \& Parveen, S. (2019). The financial cost and social influence: Factors affecting the adoption of halal cosmetics in Malaysia. Academy of Entrepreneurship Journal, 25(2), 1-11.

Annabi, C. A. \& Olajumoke Ibidapo-Obe, O. (2017). Halal certification organizations in the United Kingdom: An exploration of Halal cosmetic certification. Journal of Islamic Marketing, 8(1), 107-126. https://doi.org/10.1108/JIMA-06-2015-0045

Batu, A. \& Regenstein, J. M. (2010). Halal food certification challenges and their implications for Muslim societies worldwide. Turkish Studies - International Periodical for the Languages, Literature, and History of Turkish, 9(11), 111-130.

Balan, I. M., Popescu, A. C., Iancu, T., Popescu, G., \& Tulcan, C. (2020). Food safety versus food security in a world of famine. Journal of Advanced Research in Social Sciences and Humanities, 5(1), 20-30.

Bohari, A. M., Cheng W., \& Hin, N. F. (n.d). The competitiveness of Halal Food industry in Malaysia: A SWOT - ICT analysis. Malaysia Journal of Society \& Space, 9(1), 1-10.

COMCEM (2016). Muslim friendly tourism: Developing and marketing MFT products and services in the OIC member countries (Annual Report No: 110/A). Ankara, Turkey. Retrieved from www.comcec.org

Demirel, Y. \& Yasarsoy, E. (n.d.). Exploring consumer attitudes towards halal products. Journal of Tourismology, 3(1), 22-25.

Elasrag, H. (2016). Halal industry: Key challenges and opportunities (MPRA Paper No. 69631), Retrieved from https://mpra.ub.uni-muenchen.de/69631/.

Golnaz R., Zainalabidin, M., \& Mad Nasir, S. (2012). Assessment of consumers' confidence in halal labeled manufactured food in Malaysia. Pertanika Journal of Social Sciences \& Humanity, 20(1), $33-42$.

Hayata, R., Buttera, F. A. G., \& Kockb, U. (2011). Halal certification for financial products: a transaction cost perspective (Tinbergen Institute Discussion Paper, TI 2011-171/3).

Hussain, N., Haq, M. A., Zama, Z., \& Usman. M. (2014). Global halal food market and opportunities for Pakistan. International Journal of Education and Research, 2(3), 32-34.

Islam, T. \& Chandrasekaran, U. (2013). Halal Marketing: Growing the pie. International Journal of Management Research and Review, 3(12), 43-45.

Krishnan, S., Che Musa, C., Omar, Irsyad, Z., Nazreen, S., \& Sharifah A. (2017). The awareness of gen-Z's toward the Halal food industry. Management, 7 (1), 44-47.

Memon, N. A. (2015). Demand grows for Pakistani halal meat. Exclusive on meat. Retrieved from https://www.foodjournal.pk/2015/July-August-2015/PDF-July-August-2015/Dr-Noor-halalmeat.pdf

Murti, T. W. (n.d.). Halal lifestyle and global trade. In 7th International Seminar on Tropical Animal Production Contribution of Livestock Production on Food Sovereignty in Tropical Countries. Yogyakarta, Indonesia. 
Nain, N.A. K., Nazefah, A. H., Che I. C. I., Mohd D. M. R., Nur, S., Noor, F. Z., Norlelawati, Z., Asral, W. A. A., Normaliza, A. M., Ahmad W. M., Mustafa, A. A.H., Alina, A. R., Siti H. A. A., Imtinan, A. K., \& Norhaizam, M. S. (2013). towards a halal certification module and training program development for the pharmaceutical industry. Middle-East Journal of Scientific Research, 13, 49-53.

Pawestri, G. (2019). Jathilan: Between the Javanese sacred rituals and performance in tourism attractions. Journal of Advances in Humanities and Social Sciences, 5(5), 207-215.

Qureshi, S. S., Jamal, M. M. S., Qureshi, M., Rauf, B. H., Zulfiqar, S., \& Chand, N. (2012). A review of halal food with special reference to meat and its trade potential. The Journal of Animal and Plant Sciences, 22(2), 79-83.

Rachman, M., \& Syamsuddin. (2019). Halal industry in Indonesia: The role of sharia financial institutions in driving industrial and halal ecosystem. Al-Iqtishad: Jurnal Ilmu Ekonomi Syariah (Journal of Islamic Economics), 11(1), 23-27.

Rahim, N. H. M., Zainuddin, A. \& Sariwati, M. S. (2016). Retailing layouts for halal food supply chain: issues \& challenges. Science International, 28(2), 1941-1947.

Razak, M. I. M., Alias, Z., Samad I. H. A., Naseri, R. N. N., Ahmad N. Z. A., \& Baharuddin, F. N., (2015). Overview of halal products and services in Malaysia and the global market. International Journal of Economics, Commerce and Management, 3(3), 23-37.

Samori, Z., Ishak, A., Hayati \& Kassan, N. H. (2014). Understanding the development of halal food standards: suggestion for future research. International Journal of Social Science and Humanity, 4(6), 45-47.

Siregar, D. S. (2018). Perceptions and preferences of Muslim domestic tourists in Indonesia as a halal tourism destination (case study: Halal tourism in West Java). International Journal of Humanities, Arts and Social Sciences, 4(5), 194-202.

Sugibayashi, K., Eddy, Y., Hiroaki, T., Sabrina, D., Pajaree, S., Florencio, A., \& Gerard, L. S. (2019). Halal cosmetics: A review of ingredients, production, and testing methods. Cosmetics, 6(37), 65-69.

Sugita, I. (2017). Halal in Singapore (Global Agricultural Information Network (GAIN) Report \#SN7004).

Susilowati, I., Edy R. E., Kirana, M., Mafruhah, I., \& Radam, A. (2018). The economic and sharia value of moslem's awareness for halal food in Indonesia", Jurnal Ekonomi Pembangunan: Kajian Masalah Ekonomi dan Pembangunan, 19(1), 102-113

Suki, N. M. \& Suki, N. M. (2018). Halal cosmetic products: Do knowledge and religiosity affect. International Journal of Engineering \& Technology, 7(4.38), 764-767.

Wahab, A. R. (2004). Guidelines for the preparation of halal food \& goods for the Muslim consumers", HALAL Guidelines for the manufacturer. AmalMerge (M) Sdn. Bhd.

WEF (2015). When halal meet Islamic finance. New York, NY: The World Economic Forum (WIFE) Foundation.

Wilkins, S., Butt, M. M., Shams, F. \& Pérez, A. (2019). The acceptance of halal food in non-Muslim countries: effects of religious identity, national identification, consumer ethnocentrism \& consumer cosmopolitanism. Journal of Islamic Marketing, 10(4), 34-40.

Yasid, Farhan, F. \& Andriansyah. (2016). Factors affecting Muslim students' awareness of halal products in Yogyakarta, Indonesia. International Review of Management \& Marketing, 2016, 6(S4) 27-31. 